\title{
Znaczenie lokalnej żywności oraz krótkich łańcuchów dostaw w kształtowaniu zrównoważonego rozwoju rolnictwa i obszarów wiejskich w Unii Europejskiej
}

Joanna Michalczyk*

\section{Wprowadzenie}

Koncepcja zrównoważonego rozwoju leży w kręgu zainteresowań wielu państw na świecie. Jej początki sięgają XVIII w., kiedy to opracowano ją z myślą o gospodarce leśnej. Z czasem rozszerzono jej zakres na całą gospodarkę, co było związane z rosnącą świadomością zagrożeń o globalnym zasięgu, wynikających z nieodpowiedzialnej, czasem wręcz rabunkowej, działalności człowieka. Początkowo najbardziej niepokojące zmiany obserwowano w obszarze środowiska naturalnego, a dotyczyły one jego zanieczyszczenia oraz wyczerpywania się zasobów naturalnych, w tym energetycznych. Niebywały postęp naukowo-techniczny na przełomie XX i XXI w. oraz coraz większa skala powiązań między krajami oraz przedsiębiorstwami, głównie za sprawą liberalizacji działalności gospodarczej, skłoniły rządy poszczególnych państw do podjęcia głębszej współpracy w zakresie oddziaływania na kierunki rozwoju świata przy zachowaniu koncepcji zrównoważonego rozwoju.

Koncepcja ta, zasadniczo polegająca na dążeniu do zaspokojenia potrzeb współczesnego społeczeństwa w taki sposób, by zaspokojenie ich przez kolejne pokolenia było możliwe, ma charakter interdyscyplinarny i łączy aspekty środowiskowe, społeczne i ekonomiczne. Potrzeba jej przestrzegania stała się szczególnie ważna w przypadku sektora rolno-spożywczego - w porównaniu z innymi dziedzinami gospodarki przez długie lata częstokroć nie był on przedmiotem zainteresowania władz, które skupiały uwagę głównie na branżach przekładających się na wyższą wartość dodaną. W efekcie rolnictwo i obszary wiejskie przez długie lata pozostawały zacofane i niedoinwestowane, a ewentualne inwestycje

\footnotetext{
* Joanna Michalczyk - doktor nauk ekonomicznych, Uniwersytet Ekonomiczny we Wrocławiu, Wydział Nauk Ekonomicznych, Katedra Międzynarodowych Stosunków Gospodarczych, e-mail: joanna.michalczyk@ue.wroc.pl.
} 
miały przede wszystkim przynosić zyski. W konsekwencji prowadzono nazbyt intensywną i silnie skoncentrowaną produkcję, która zaburzała globalną równowagę ekologiczną oraz wywoływała szereg innych niekorzystnych zjawisk, także natury ekonomicznej, społecznej i zdrowotnej.

Potrzeba zachowania zrównoważonego rozwoju rolnictwa jest wynikiem jego wielofunkcyjności. Można bowiem wskazać jego rolę w dostarczaniu dóbr zarówno rynkowych, jak i pozakomercyjnych. Wydaje się, że te ostatnie zaczynają nabierać szczególnego znaczenia, ponieważ ta funkcja rolnictwa jest ciągle rozbudowywana. Jedna z wielu klasyfikacji pozakomercyjnych dziedzin oddziaływania rolnictwa dzieli je na tzw. rolnictwo zielone (dotyczące m.in. utrzymania dobrostanu zwierząt i bioróżnorodności), błękitne (dotyczące m.in. zarządzania zasobami, poprawy jakości wód, wytwarzania energii wodnej i wiatrowej), żółte (utrzymanie spójności i żywotności obszarów wiejskich) oraz białe (zapewnienie bezpieczeństwa żywnościowego i produkcja „zdrowej” żywności) (Wilkin 2017).

Przytoczone funkcje wskazują na dwoisty charakter oddziaływania rolnictwa na środowisko naturalne. $Z$ jednej strony współtworzy ono przyrodę, a $\mathrm{z}$ drugiej niekontrolowana lub niewłaściwa aktywność producentów rolnych niszczy je, wywołując także negatywne skutki pozaprzyrodnicze. Stąd zrównoważony rozwój rolnictwa i obszarów wiejskich leży w polu zainteresowania wielu organizacji międzynarodowych, w tym Unii Europejskiej, która nadała tej kwestii szczególną rangę w nowym okresie finansowania polityki rolnej.

Celem niniejszego opracowania jest określenie znaczenia lokalnej żywności oraz krótkich łańcuchów dostaw we wdrażaniu koncepcji zrównoważonego rozwoju rolnictwa i obszarów wiejskich oraz przedstawienie działań Unii Europejskiej w tym zakresie. Działania te skupiają się w ramach Wspólnej Polityki Rolnej. Do przygotowania artykułu posłużono się metodą opisową oraz analizą literatury.

\section{Koncepcja zrównoważonego rozwoju - rys historyczny}

Pierwsze wzmianki na temat konieczności zachowania zrównoważonego rozwoju pojawiły się, jak już wspomniano, w I poł. XVIII w. - w odpowiedzi na nadmierne wówczas wycinanie lasów na terenie Niemiec. Nieprzerwany rozwój cywilizacyjny i związane z nim liczne korzyści i zagrożenia dla ludzkości oraz pogłębianie więzi społeczno-gospodarczych między różnymi państwami przyczyniły się do przeniesienia później tej koncepcji z poziomu krajowego na międzynarodowy. Oficjalnie po raz pierwszy termin „zrównoważony rozwój” pojawił się podczas zorganizowanej w 1972 r. Konferencji ONZ w Sztokholmie. Był to tzw. pierwszy Szczyt Ziemi, którego przewodnie hasło brzmiało: „mamy tylko jedną Ziemię”. Podkreślono wówczas znaczenie jednej z funkcji państwa, jaką jest ochrona środowiska, i uchwalono Deklarację Konferencji Narodów Zjednoczonych w sprawie Naturalnego Środowiska Człowieka (Wyżnikiewicz 2014, s. 249; Kociszewski 2013, s. 28). 
Zainteresowanie krajów problematyką kontrolowanego rozwoju poskutkowało utworzeniem w 1983 r. Światowej Komisji ds. Środowiska i Rozwoju ONZ. Komisja ta, zwana również Komisją Brundtland (od nazwiska norweskiej lekarki i polityka), podjęła się głębszego dopracowania koncepcji zrównoważonego rozwoju, którą przedstawiła w opublikowanym w 1987 r. raporcie pt. „Nasza wspólna przyszłość". Mianem koncepcji zrównoważonego rozwoju określono koncepcję postulującą zaspokajanie potrzeb dzisiejszej społeczności bez zagrożenia zaspokojenia ich przez przyszłe pokolenia. Działalność komisji nie tylko przyczyniła się do wyraźnego umiędzynarodowienia problematyki zrównoważonego rozwoju, ale również do przeniesienia jej poza obszar środowiska naturalnego (Wyżnikiewicz 2014, s. 249).

Dalsze propagowanie koncepcji zrównoważonego rozwoju nastąpiło w czasie kolejnego spotkania państw ONZ w 1992 r. w Rio de Janeiro (tzw. drugi Szczyt Ziemi), którego hasło przewodnie brzmiało: „środowisko i rozwój”. Nasilono wówczas rozmowy, zwłaszcza na temat ekologii, i uchwalono dokumenty, które miały pomóc krajom solidaryzować się $\mathrm{w}$ działaniu na rzecz zrównoważonego rozwoju. Były to w szczególności: Ramowa konwencja Narodów Zjednoczonych w sprawie zmian klimatu, Agenda 21 (katalog celów ochrony do osiągnięcia w XXI w.), Konwencja o zachowaniu różnorodności biologicznej oraz Deklaracja dotycząca kierunku rozwoju, ochrony i użytkowania lasów (Szczyt Ziemi 1992).

Warto zaznaczyć, że koncepcja zrównoważonego rozwoju opracowana pod przewodnictwem Komisji Brundtland stała się w następnych latach fundamentem licznych interdyscyplinarnych programów i działań na skalę międzynarodową. Ponadto zmobilizowała ona kraje do integracji działań w trzech kluczowych obszarach: wzrostu gospodarczego i równomiernego podziału korzyści, ochrony zasobów naturalnych i środowiska oraz rozwoju społecznego (Morżoł 2017). Szczególną uwagę poświęcono kategorii zachowania tzw. sprawiedliwości międzypokoleniowej, która nakłada obowiązek zapewnienia dostępu do niezbędnych surowców naturalnych następnym pokoleniom oraz pozostawienia im środowiska naturalnego w stanie niepogorszonym (Pawłowski, Pawłowski 2014, s. 241-242). Wyostrzona w koncepcji zrównoważonego rozwoju idea sprawiedliwości międzygeneracyjnej stała się ważna w przypadku rozwiązywania wielu globalnych problemów, zwłaszcza potrzeby wyżywienia całej ludzkości. W tym kontekście uzmysłowiono sobie konieczność dbałości o środowisko obszarów wiejskich, utrzymania ich żywotności, a także wdrożenia działań zapobiegających migracji do miast (Kociszewski 2013, s. 28; Pawłowski, Pawłowski 2014, s. 242).

Niepohamowany rozwój gospodarczy państw, coraz trudniej sterowalny ze względu na postępujące procesy internacjonalizacji i globalizacji, mobilizował rządy do kolejnych spotkań, w czasie których nie tylko doskonalono koncepcję zrównoważonego rozwoju, ale także próbowano wypracować podejście łagodzące brak równowagi między poszczególnymi społecznościami oraz rozwiązywać globalne problemy świata (Wyżnikiewicz 2014, s. 249). 
W kalendarium dalszych spotkań państw ONZ poświęconych pracom nad zachowaniem zrównoważonego rozwoju szczególnie ważny był rok 2000, kiedy to zorganizowano Szczyt Milenijny. Zdefiniowano wówczas tzw. Milenijne Cele Rozwoju, które miały zostać osiągnięte przez wszystkie państwa członkowskie do roku 2015. Dotyczyły one w szczególności zrównoważonych metod gospodarowania zasobami naturalnymi, eliminacji głodu oraz równości płci (Milenijne 2017).

Dwa lata później zorganizowano spotkanie w Johannesburgu (tzw. Szczyt Ziemi 2002 lub Rio +10), które miało być przyczynkiem do dyskusji nad problematyką globalnego zrównoważonego rozwoju. Spotkanie to miało pomóc państwom zidentyfikować zmiany, jakie zaszły w ciągu minionej dekady, oraz wypracować spójne działania na rzecz równomiernego podziału korzyści z globalizacji. Zwracając uwagę na problem głodu i jednoczesnej nadkonsumpcji oraz na potrzebę zintegrowania prac $\mathrm{w}$ zakresie promocji zrównoważonych wzorców produkcji i konsumpcji, wyodrębniono pięć obszarów współpracy; były to: woda, energia, zdrowie, rolnictwo i różnorodność biologiczna (Szczyt Ziemi 2002). Następne spotkanie państw ONZ, w ramach tzw. Szczytu Rio +20, zorganizowane w 2012 r., stanowiło odnowienie i polityczne umocnienie współpracy krajów zaangażowanych w ideę zrównoważonego rozwoju. Podkreślono potrzebę realizacji wskazanych wcześniej celów milenijnych oraz dokonano ich hierarchizacji. Przyjęto wiele zobowiązań, w tym m.in. dziesięcioletni Pakiet Programów Dotyczących Zrównoważonej Konsumpcji i Produkcji (Wystąpienie 2017; Cel 2017).

Mimo że zaangażowanie państw w realizację postulatów dotyczących zrównoważonego rozwoju jest coraz większe, można dostrzec liczne trudności z urzeczywistnieniem tej koncepcji. Są one częściowo spowodowane konfliktem interesów, zwłaszcza ze strony wiodących gospodarek światowych, takich jak Chiny, Indie czy USA, dla których wdrażanie działań wpierających zrównoważony rozwój jest równoznaczne z rosnącymi kosztami produkcji. Jest to sprzeczne $\mathrm{z}$ ich dążeniem do minimalizacji tych kosztów w celu utrzymania pozycji konkurencyjnych producentów światowych (Kociszewski 2013, s. 34). Warto jednak zaznaczyć, że idea zrównoważonego rozwoju jest powszechnie akceptowana w rozwiniętych państwach europejskich, co przekłada się na jej obecność w systemach instytucjonalno-prawnych krajów, a także w polityce unijnej (Kociszewski 2013, s. 35). Jednym z przejawów tego jest opracowanie przez państwa UE strategii na rzecz zatrudnienia i wzrostu „Europa 2020”. Ma ona na celu stworzenie warunków do inteligentnego i zrównoważonego wzrostu gospodarczego sprzyjającego włączeniu społecznemu poprzez skoncentrowanie działań w pięciu obszarach: zatrudnienia, innowacyjności, edukacji, walki z ubóstwem oraz klimatu i energii (Europa 2017). Liczne odniesienia do zrównoważonego rozwoju można znaleźć także w założeniach poszczególnych polityk wspólnotowych, wśród których na szczególną uwagę zasługuje polityka rolna i obszarów wiejskich. 


\section{Koncepcja zrównoważonego rozwoju rolnictwa i obszarów wiejskich}

Koncepcja zrównoważonego rozwoju jest głęboko zakorzeniona w polityce państw członkowskich Unii Europejskiej. Jako że jest pojęciem interdyscyplinarnym, można ją analizować w odniesieniu do wielu płaszczyzn działalności człowieka. Pojęcie zrównoważonego rozwoju rolnictwa i obszarów wiejskich jest właśnie wynikiem przeniesienia koncepcji na poziom sektorowy. Jego trzonem są determinanty, które także określają ogólnie pojmowany zrównoważony rozwój. Są to w szczególności: wymiar ekologiczny - odnoszący się do wpływu postępu cywilizacyjnego na środowisko naturalne, wymiar ekonomiczny - dotyczący alokacji i dystrybucji ograniczonych dóbr oraz wymiar społeczny - skupiający się na warunkach egzystencji człowieka, relacjach i wartościach (Zegar 2012, s. 133).

Warto zaznaczyć, że pomimo zasadniczej równorzędności czynników współtworzących ideę zrównoważonego rozwoju, w przypadku rolnictwa i obszarów wiejskich czynnik środowiskowy wydaje się nieco ważniejszy - zwłaszcza w sytuacjach, w których efekty realizacji celów rozwojowych uzależnione są bezpośrednio od przyrody (Żmija 2014, s. 150). Wspomniane kwestie środowiskowe oddziałują nie tylko na tradycyjną funkcję produkcyjną rolnictwa, ale również na inne, w tym na przestrzenną, rekreacyjną, turystyczną, społeczno-kulturową. Środowisko naturalne decyduje też o warunkach bytowych człowieka, a zatem wpływa na jego możliwości rozwojowe. Jak wspomniano, rolnictwo z jednej strony współtworzy środowisko, z drugiej - w przypadku niewłaściwej działalności człowieka może je niszczyć. Niezmiernie ważne jest zatem podejmowanie działań w celu zrównoważenia tej zależności.

Warto zaznaczyć, że realizacja idei zrównoważonego rozwoju rolnictwa i obszarów wiejskich nastręcza wiele trudności. Są one wynikiem nie tylko powszechnej tendencji do faworyzowania w społeczeństwie teraźniejszości kosztem przyszłości, ale również wkraczania w erę tzw. turbokapitalizmu, który charakteryzuje się osłabieniem roli władz krajowych w rozwiązywaniu problemów społeczno-gospodarczych - wskutek deregulacji, prywatyzacji i liberalizacji (Pawłowski, Pawłowski 2014, s. 242-244). Dla rolnictwa i obszarów wiejskich szczególnie poważnym problemem w kontekście społecznym jest niski poziom zamożności farmerów, a w kontekście ekonomicznym są nim ograniczone możliwości inwestycyjne. Ponadto niski poziom wykształcenia oraz świadomości konieczności ochrony środowiska nie pozwalają skutecznie prowadzić polityki ekologicznej (Żmija 2014, s. 151).

W literaturze przedmiotu można spotkać zróżnicowane podejścia do definiowania zrównoważonego rozwoju rolnictwa oraz obszarów wiejskich. Te dwie płaszczyzny (rolnictwo i obszary wiejskie) bywają zarówno łączone, jak i traktowane z osobna. Jednak jeśli uwzględni się ścisły związek pomiędzy nimi, zasadne 
wydaje się posługiwanie jedną koncepcją, wspólną dla obu kategorii. Do najbardziej znanych należy definicja opracowana przez FAO w 1989 r. i spójna z podejściem Komisji Brundtland do problematyki zrównoważonego rozwoju. Stanowi ona, że jest to sposób wykorzystywania i ochrony zasobów naturalnych przy takim zorientowaniu zmian technologicznych $i$ instytucjonalnych, aby osiagnać $i$ podtrzymać zaspokojenie ludzkich potrzeb $w$ perspektywie wielopokoleniowej. Tak rozumiany zrównoważony rozwój $w$ rolnictwie, rybołówstwie i leśnictwie, chroniacy ziemię, wodę, rośliny, gatunki zwierząt, jest nieszkodliwy dla środowiska, odpowiedni pod względem technologicznym, rentowny i spolecznie akceptowalny (Michalczyk 2014, s. 338; por. Hardaker 2017).

Z kolei w przytaczanym wcześniej dokumencie Agenda 21, uchwalonym przez państwa ONZ w 1992 r., zwraca się uwagę na potrzebę stworzenia określonych warunków dla zrównoważonego rozwoju rolnictwa i obszarów wiejskich w wyniku realizacji priorytetowych celów, którymi są zrównoważone zwiększenie produkcji żywności oraz wzmocnienie bezpieczeństwa żywnościowego. To z kolei wymusza podjęcie działań edukacyjnych i jednoczesne wykorzystanie bodźców ekonomicznych, a także rozwój technologii, które powinny nie tylko oddziaływać na produkcję rynkową, ale również zapewniać przewidywalne dostawy wartościowej zdrowotnie żywności, także dla ludności żyjącej na skraju ubóstwa. Dodatkowo oczekuje się zwiększenia zatrudnienia i przychodów w rolnictwie i na obszarach wiejskich, m.in. dzięki dywersyfikacji działalności, przestrzegając zasad ochrony i odnawialności środowiska. $\mathrm{W}$ przytoczonej interpretacji zrównoważonego rozwoju zwrócono uwagę na trzy zasadnicze obszary: bezpieczeństwo dostaw, wspieranie zatrudnienia i eliminację ubóstwa oraz zachowanie zasobów naturalnych i ochronę środowiska (Agenda 2017). W zakresie pierwszego obszaru pożądane stało się zadbanie nie tylko o wielkość, ale również o jakość dostaw (z uwzględnieniem podtrzymania regionalnej i lokalnej specyfiki produkcji). Z kolei w zakresie obszarów drugiego i trzeciego wymagana jest m.in. dywersyfikacja działalności wraz z rozwijaniem aktywności pozarolniczej.

Przedstawione postulaty i przesłanki wdrażania koncepcji zrównoważonego rozwoju rolnictwa i obszarów wiejskich znalazły odzwierciedlenie w politykach wielu państw, w tym krajów Unii Europejskiej.

\section{Znaczenie zrównoważonego rozwoju w polityce rolnej Unii Europejskiej}

Polityka rolna Unii Europejskiej jest jedną z najstarszych i najbardziej złożonych polityk i w ciągu minionych lat często się zmieniała. Zmiany te wynikały nie tylko $\mathrm{z}$ długiego okresu jej funkcjonowania, ale także z kolejnych rozszerzeń ugrupowania oraz z potrzeby dostosowania jej do zmieniającego się otoczenia i światowych wyzwań. 
Wspólna Polityka Rolna, mająca za sobą ponad 50 lat funkcjonowania, została istotnie przebudowana. W pierwszych latach funkcjonowania była ukierunkowana na tworzenie mechanizmów wsparcia rolnictwa, pozwalających sprostać międzynarodowej konkurencji. Określono wówczas zasady funkcjonowania poszczególnych rynków rolnych, opierając się na zasadzie solidarnego ponoszenia kosztów przez członków ugrupowania. Szczególne traktowanie sektora rolnego powiązano z potrzebą dominującego udziału finansowania WPR we wspólnotowym budżecie. Sformułowane wówczas cele, zasady, a zwłaszcza mechanizmy polityki rolnej były ukierunkowane przede wszystkim na rozwiązywanie problemów związanych z bieżącym funkcjonowaniem rolnictwa i dostarczaniem przez nie produktów rolno-spożywczych. W pierwszym etapie jej funkcjonowania ( $\mathrm{tj}$. do lat 80.) skupiano się więc głównie na problemach ekonomicznych, co pozwoliło na osiągnięcie samowystarczalności dostaw żywności oraz stabilizację cen. Jednocześnie uwypukliły się problemy natury społecznej oraz dotyczące degradacji środowiska naturalnego. Była to zatem polityka niezgodna $\mathrm{z}$ koncepcją zrównoważonego rozwoju (Zegar 2012, s. 288).

Z wyzwaniami natury społeczno-środowiskowej, dotyczącymi m.in. wyludnienia niektórych obszarów rolnych oraz zanieczyszczenia, próbowano się zmierzyć już w 1969 r., opracowując - jak się okazało nieskuteczny - plan Mansholta. Dopiero przeprowadzona w 1992 r. reforma MacSharry'ego zmieniła sposób postrzegania rolnictwa, które ściśle powiązano z krajobrazem i życiem wiejskim. Przypisano zatem europejskiemu rolnictwu wiele różnorodnych zadań, odchodząc od jego jednostronnego zorientowania na wydajność na rzecz jego wielofunkcyjności (Zegar 2012, s. 291). Takie podejście odzwierciedlało się w szerzeniu praktyk charakterystycznych dla rolnictwa zrównoważonego, a nawet ekologicznego, nie tylko w celu zdywersyfikowania działalności, ale także po to, aby odwrócić lub zatrzymać niekorzystne zmiany w środowisku naturalnym wywołane wieloletnim funkcjonowaniem modelu industrialnego rolnictwa. Po raz pierwszy wprowadzono pakiet programów rolno-środowiskowych (Świderska 2017; Zegar 2012, s. 287-293); moment ten można uznać za istotny w procesie tworzenia polityki rozwoju obszarów wiejskich, wcześniej funkcjonującej jako strukturalna polityka rolna (Borowiec 2011, s. 432). Wydzielenie w polityce rolnej filaru odnoszącego się do rozwoju obszarów wiejskich podkreśliło rangę działań prowadzonych w tej dziedzinie oraz wskazało na konieczność ich pogłębiania, tak by móc lepiej wspierać zrównoważony rozwój. Warto dodać, że te i inne działania były inspirowane zorganizowanym w tym czasie przez państwa ONZ drugim Szczytem Ziemi, który poświęcono łączeniu ochrony przyrody z dalszym rozwojem społeczno-gospodarczym.

Kierunek zmian zainicjowanych pakietem MacSharry'ego kontynuowano w następnych latach, czego efektem było przyjęcie w 1999 r. dokumentu Agenda 2000. Jego opracowanie było poprzedzone podpisaniem Traktatu Amsterdamskiego, ważnego dla trwałego włączenia zrównoważonego rozwoju do polityk 
wspólnotowych, w tym rolnej. Innym, także istotnym elementem wiążącym politykę rolną ze zrównoważonym rozwojem było sformułowanie w $1998 \mathrm{r}$. w dokumencie Explanatory Memorandum definicji tzw. europejskiego modelu rolnictwa, podkreślającego jego znaczący wkład w utrzymywanie zasobów naturalnych obszarów wiejskich. Model ten oparty jest na rolnictwie rodzinnym, wielofunkcyjnym oraz zrównoważonym (Kociszewski 2013, s. 106). Agenda 2000 przyniosła pogłębioną reorganizację WPR, wyodrębniając w niej filar pierwszy, dotyczący polityki rynkowej, i drugi, skupiający się na zrównoważonym rozwoju obszarów wiejskich. Przyjęte cele zreformowanej polityki dotyczyły: poprawy konkurencyjności, bezpieczeństwa zdrowotnego i jakości żywności, utrzymania standardu życia i stabilnych dochodów w rolnictwie, lepszej integracji celów środowiskowych w WPR oraz dywersyfikacji działalności (Zegar 2012, s. 293).

Kolejne zmiany polityki rolnej, w ramach reformy Fischera, dotyczyły jej uproszczenia i zwiększenia skuteczności drugiego filaru. Istotne zmiany zaszły również w filarze pierwszym, a sprowadzały się one przede wszystkim do oddzielenia płatności bezpośrednich od wielkości produkcji. Ponadto udoskonalono funkcjonowanie mechanizmów integrujących rolnictwo ze środowiskiem, zainicjowanych na podstawie Agendy 2000. Są to w szczególności: zasada wzajemnej zgodności, promująca bardziej zrównoważone rolnictwo, zasada decouplingu, wzmagająca rynkowe nastawienie producentów rolnych, oraz zasada modulacji, pozwalająca na przenoszenie środków finansowych z pierwszego do drugiego filaru polityki (Zegar 2012, s. 294-295). W trakcie dalszych prac Unii nad udoskonalaniem polityki rolnej i pogłębianiem jej powiązań z koncepcją zrównoważonego rozwoju nastąpiło wyraźne przesunięcie punktu ciężkości ze wsparcia rynkowego na rzecz rozwoju obszarów wiejskich (Health 2017). Każdy z filarów polityki, choć w różnym stopniu, został włączony w produkcję żywności, ochronę przyrody oraz utrzymanie terenów wiejskich.

Po raz kolejny ranga idei zrównoważonego rozwoju została podkreślona w komunikacie Komisji Europejskiej z dnia 18 listopada 2010 r. (Komunikat Komisji 2010, s. 5-6). W nakreślonej ścieżce ewolucji polityki rolnej wskazano wyzwania, z jakimi musi się zmierzyć europejskie rolnictwo. Są to w szczególności: bezpieczeństwo żywnościowe wymagające m.in. poprawy zdolności produkcyjnych rolnictwa przy zachowaniu jakości i utrzymaniu lokalnej wytwórczości, zanieczyszczenie środowiska naturalnego i zmieniający się klimat - za ich występowanie winą obarcza się m.in. niewłaściwe praktyki w rolnictwie - oraz równowaga terytorialna, za którą w dużej mierze odpowiedzialne jest rolnictwo, podejmujące na obszarach wiejskich różne formy aktywności gospodarczej, takie jak przetwórstwo żywności czy turystyka. Założono również, że zmierzenie się z tymi wyzwaniami przyczyni się do realizacji strategii Europa 2020 w zakresie inteligentnego, zrównoważonego rozwoju sprzyjającego włączeniu społecznemu. W kontekście opisanych wyzwań polityce rolnictwa europejskiego postawiono trzy główne cele: 
1) opłacalną produkcję żywności - ze szczególnym uwzględnieniem dochodów rolników, których siła przetargowa i pozycja konkurencyjna jest słabsza w porównaniu z innymi ogniwami łańcucha żywnościowego, i od których wymaga się przestrzegania standardów w zakresie ochrony środowiska oraz w produkcji;

2) zrównoważone gospodarowanie zasobami naturalnymi i działania na rzecz klimatu (m.in. szerzenie ekologicznych praktyk produkcyjnych);

3) zrównoważony rozwój terytorialny - oparty na zachowaniu struktur społecznych na obszarach wiejskich i dbałości o dywersyfikację działalności, zwłaszcza o lokalnym znaczeniu.

Warto także dodać, że zachowanie różnorodności strukturalnej systemów rolniczych oraz wsparcie małych gospodarstw i ich systemów produkcji przyczyniają się do wzrostu atrakcyjności i tworzenia tożsamości regionów wiejskich (Komunikat Komisji 2010, s. 8-9).

W trakcie dalszych prac nad ostatecznym kształtem polityki rolnej na nowy okres programowy, tj. lata 2014-2020, Komisja Europejska osiągnęła porozumienie z Parlamentem Europejskim i Radą Ministrów UE. Efektem tego było opublikowanie w 2013 r. założeń nowej polityki rolnej, dotyczących bardziej sprawiedliwych i ukierunkowanych na ekologię płatności bezpośrednich, wzmocnienia roli producenta rolnego w łańcuchu żywnościowym oraz poprawy skuteczności instrumentów tej dziedziny polityki (Komunikat prasowy 2013). W tym samym czasie Komisja Europejska wyodrębniła cztery kluczowe obszary tematyczne prac organów unijnych na rzecz reformy WPR (Notatka 2013). Są to w szczególności: płatności bezpośrednie, wspólna organizacja rynków produktów rolnych, rozwój obszarów wiejskich oraz rozporządzenie horyzontalne w zakresie finansowania, zarządzania i monitorowania WPR. Warto zaznaczyć, że prace prowadzone w każdym z tych obszarów mają - w mniejszym bądź większym stopniu - sprzyjać zrównoważonemu rozwojowi sektora rolnego i obszarów wiejskich. Na szczególną uwagę, jeśli chodzi o tego typu działania, zasługuje wzmocnienie pozycji rolnika w łańcuchu dostaw żywności oraz promowanie krótkich łańcuchów dostaw.

\section{Żywność lokalna i krótkie łańcuchy dostaw jako kluczowe elementy zmodyfikowanej Wspólnej Polityki Rolnej}

Lokalna produkcja żywności jest trwałym elementem rozwoju obszarów wiejskich, a w ostatnich latach obserwuje się jej szczególny rozkwit, m.in. za sprawą coraz bardziej wysublimowanych potrzeb konsumentów. Pomimo tego w europejskim prawodawstwie wciąż brakuje wspólnej, jednoznacznej i precyzyjnej definicji zarówno lokalnej żywności, jak i związanego z nią pojęcia krótkiego łańcucha dostaw. Definicja żywności produkowanej lokalnie z oczywistych względów powinna określać limit odległości pomiędzy miejscem jej produkcji a miejscem 
sprzedaży. Jednak ani w prawodawstwie, ani w literaturze, nie ma zgodności co do takiego limitu, który w zależności od ujęcia i kraju może wynosić nawet $100 \mathrm{~km}$. Niekiedy za żywność lokalną uznaje się produkty pochodzące z danego, szczególnie małego, państwa. W związku z tymi rozbieżnościami to konsument ostatecznie ocenia, czy produkt jest pochodzenia lokalnego (Sprawozdanie 2013, s. 4-5; Local 2012, s. 4-5). Warto jednak zaznaczyć, że zazwyczaj są to towary o unikatowych cechach, takich jak smak, świeżość, wysoka jakość, przynależność kulturowa, tradycyjne metody produkcji, pochodzenie składników czy warunki zrównoważonej produkcji.

Rozbieżności pojawiają się również, jeśli chodzi o pojmowanie określenia „krótkie łańcuchy dostaw”. Choć są one często częścią lokalnych systemów żywnościowych, to mogą być również rozbudowane przestrzennie, tak aby obejmowały produkty z różnych stref klimatycznych pozyskiwane w sposób bezpośredni (Definicja 2017). Ponadto niektóre państwa UE wprowadziły formalne definicje krótkich łańcuchów dostaw; we Francji w przypadku takich łańcuchów może występować maksymalnie jeden pośrednik, a prawo włoskie określa je jako sprzedaż bezpośrednią (Local 2012, s. 5). Niemniej jednak, pomimo pewnych rozbieżności w interpretowaniu przytoczonych pojęć, można wyodrębnić wiele ich wspólnych cech - spójnych i tworzących na wysokim poziomie ogólności pewien obraz koncepcji żywności lokalnej i krótkich łańcuchów dostaw. Są to w szczególności: możliwie krótka odległość między producentem a konsumentem oraz ograniczona liczba pośredników. Co więcej, biorąc pod uwagę fakt, że produkcja, przetwarzanie i obrót żywnością lokalną oraz jej spożycie odbywają się na stosunkowo małym obszarze geograficznym, zwraca się uwagę na komunikację i porozumienie między producentem a konsumentem, tak aby nabywca docenił wartość kupowanych produktów i wykazał permanentną chęć ich konsumpcji (Local 2012, s. 5; Sprawozdanie 2013, s. 4).

Poprawa funkcjonowania łańcuchów dostaw mieści się w jednym z sześciu priorytetów nowej polityki rozwoju obszarów wiejskich UE i dotyczy umocnienia w nim roli producentów rolnych oraz lepszego powiązania ich funkcjonowania $\mathrm{z}$ rynkiem. Priorytetowe znaczenie łańcuchów dostaw żywności zostało poruszone także w rezolucji Parlamentu Europejskiego z czerwca 2011 r., w której, mając na względzie zachowanie bezpieczeństwa żywnościowego, zwraca się uwagę na opracowanie globalnych działań zaradczych w związku z zaistniałym zjawiskiem spekulacji surowcami rolnymi oraz skrajnych wahań cen destabilizujących sytuację dochodową rolnictwa (Rezolucja 2011). Przypisanie rolnictwu szczególnej rangi w łańcuchu dostaw żywności jest wynikiem jego słabszej pozycji przetargowej w stosunku do pozostałych ogniw, tj. zajmujących się przetwórstwem, handlem hurtowym oraz detalicznym. Rolnicy, będąc najbardziej oddaleni od finalnego konsumenta, mają najmniejszy wpływ na cenę końcową, a zatem osiągają najmniejsze korzyści z tytułu tworzenia wartości w procesie produkcji. Widoczna po stronie rolnictwa asymetria siły przetargowej jest wynikiem nie tylko jego 
specyfiki, ale również licznych niedostatków inwestycyjnych, będących w dużej mierze efektem niskiego poziomu konsolidacji tego sektora względem pozostałych ogniw omawianego łańcucha. Warto jednak zwrócić uwagę na to, że chociaż spoczywający na europejskich producentach rolnych obowiązek przestrzegania norm dotyczących ochrony środowiska, dobrostanu zwierząt i bezpieczeństwa żywności z jednej strony jest wysoce uciążliwy dla wytwórców, to z drugiej strony może być wykorzystywany jako atut $\mathrm{w}$ świadczeniu usług i oferowaniu produktów niebędących powszechnymi na skalę światową. Dotyczy to zwłaszcza żywności niszowej, przypisanej określonemu regionowi czy produkowanej według tradycyjnych receptur.

Należy wspomnieć, że poprawa funkcjonowania łańcuchów dostaw żywności ma daleko idące konsekwencje i pozwala na osiągnięcie wskazanych wcześniej głównych celów Wspólnej Polityki Rolnej, dotyczących opłacalności produkcji, zrównoważonego gospodarowania zasobami oraz wsparcia zatrudnienia - spójnych z interpretacją pojęcia zrównoważonego rozwoju. Zgodnie z omawianą rezolucją Parlamentu z 2011 r. usprawnienie działania łańcuchów dostaw miałoby dotyczyć m.in. wzmocnienia siły przetargowej producentów (np. poprzez ich konsolidowanie się), zachowania większej przejrzystości cen żywności oraz zwalczania nieuczciwych praktyk handlowych. W priorytecie trzecim Programu Rozwoju Obszarów Wiejskich 2014-2020, dotyczącym właśnie poprawy organizacji łańcucha żywnościowego, określono również szczegółowe działania ukierunkowane na lepsze zintegrowanie głównych producentów z łańcuchem żywnościowym - za pomocą systemów jakości, promocji na rynkach lokalnych, krótkich cykli dostaw, grup producentów i organizacji międzybranżowych - a także na wspieranie zarządzania ryzykiem w gospodarstwach rolnych (Wstępny 2013).

W kontekście zmian zachodzących na globalnym rynku żywnościowym - spowodowanych m.in. poprawą dochodów konsumentów i poziomu ich wykształcenia oraz pogłębioną świadomością o negatywnych konsekwencjach spożywania w nadmiarze żywności wysoko przetworzonej, często o małych wartościach odżywczych, a czasem także niewiadomego pochodzenia - propagowanie krótkich łańcuchów dostaw oraz lokalnej żywności nabiera strategicznego znaczenia dla dalszego rozwoju rolnictwa UE. Zapewnia ono wzrost dochodów producentów żywności, oddziałuje na sposób zaspokajania potrzeb jej konsumentów oraz przyczynia się do zrównoważonego rozwoju rolnictwa i obszarów wiejskich.

Można wskazać wiele korzyści natury ekonomicznej, społecznej oraz środowiskowej wynikających z popularyzowania krótkich łańcuchów dostaw. Do pierwszej grupy zaliczają się rozszerzenie asortymentu europejskich produktów lokalnych oraz zapewnienie nowych miejsc pracy i podtrzymanie ich, zwłaszcza na obszarach o niekorzystnych warunkach gospodarowania (np. górskich). Ponadto rozwój produkcji lokalnej może być bodźcem ożywiającym i poprawiającym 
wizerunek regionów dotychczas mało znanych bądź marginalizowanych (Projekt 2017, s. 2). Warto dodać, że Unia Europejska może pochwalić się bogatym dziedzictwem kulinarnym, które powinno być w pełni wykorzystywane, m.in. dzięki promocji lokalnej żywności.

Jeśli chodzi o korzyści społeczne, to należy zwrócić uwagę na pogłębianie powiązań producentów z konsumentami. Oparcie ich na zaufaniu i wzajemnym porozumieniu niekiedy kończy się zawiązaniem trwałego partnerstwa, polegającego na aktywnym włączeniu nabywców żywności w procesy produkcyjne, np. poprzez tworzenie i utrzymanie przez nich lokalnych systemów żywnościowych oraz krótkich łańcuchów dostaw w danym rejonie. Powiązania takie są widoczne w wielu krajach Europy. Niekiedy w efekcie głębszej współpracy konsumenci, w ramach tzw. rolnictwa wspieranego, dzielą z producentem ryzyko i korzyści związane z produkcją, ponosząc część jej kosztów, w zamian za regularne dostawy określonych produktów. Taka forma współpracy jest szczególnie widoczna na Węgrzech (Local 2012, s. 9). Co więcej, propagowanie lokalnych, tradycyjnych czy sezonowych produktów pogłębia spójność społeczną (konsumentów, producentów i sprzedawców), a także przyczynia się do poprawy stanu środowiska naturalnego i do zachowania walorów organicznych żywności (które w długich łańcuchach dostaw mogą się zmieniać lub być celowo modyfikowane). W przypadku krótkich łańcuchów dostaw producenci są też w stanie lepiej i szybciej reagować na potrzeby konsumentów, oferując im produkty znanego pochodzenia, w odpowiednich ilościach, często po niższych cenach. Warto zaznaczyć, że przytoczone partnerstwo jest tylko jedną z form krótkich łańcuchów dostaw. Inne spotykane rozwiązania to np. indywidualna sprzedaż bezpośrednia przez osoby fizyczne, będąca najprostszą postacią krótkiego łańcucha dostaw, czy też jej forma zbiorowa. Ta ostatnia odmiana łańcucha może opierać się na sprzedaży prowadzonej wspólnie przez kilka spółdzielni producentów (Local 2012, s. 7). W nowej polityce rolnej szeroko rozumiane podejście partnerskie, nastawione na współpracę z różnymi podmiotami ( $\mathrm{w}$ tym z konsumentami), jest ważnym narzędziem rozwoju obszarów wiejskich w zakresie wspierania lokalnych rynków żywnościowych. Niesie ono możliwości zwiększania sprzedaży i przyciągnięcia nowych klientów, co w rezultacie może zaowocować silniejszymi powiązaniami między lokalnym rolnictwem, turystyką a sektorem przetwórczym (Żywność 2017; Raszeja-Ossowska 2017).

Biorąc pod uwagę ograniczoną odległość transportu żywności lokalnej od producenta do konsumenta, do korzyści natury środowiskowej wynikających ze zmniejszania liczby pośredników w łańcuchu dostaw należy również zaliczyć mniejszą emisję gazów cieplarnianych do atmosfery. Pomiar dystansu dzielącego producenta żywności od jej konsumenta dokonywany jest za pomocą tzw. food miles (Food 2017). Im wyższa wartość wskaźnika, tym większy wpływ danego łańcucha dostaw na poziom zanieczyszczenia środowiska naturalnego. Konsumpcja produktów lokalnych wiąże się z ograniczeniem skali przewozu żywności, co 
przekłada się na niższe koszty jej dostarczenia oraz mniejszą emisję spalin przez środki transportu. Dodatkowo odciążana jest infrastruktura drogowa, co sprzyja poprawie bezpieczeństwa na drogach.

\section{Podsumowanie}

W kontekście różnorodnych wyzwań współczesnej gospodarki światowej - do których należą w szczególności: dodatni przyrost ludności, zmiany klimatyczne, utrata obszarów produkcji żywności na rzecz uprawy roślin na cele energetyczne, a także rozwijanie produkcji rolnej przy mniejszym zużyciu wody i energii oraz ograniczenie jej chemizacji czy zanik bioróżnorodności - rozwój lokalnych systemów żywności, oznaczających produkcję, przetwórstwo i obrót na stosunkowo małym obszarze, jest szczególnie ważny. Ma on istotny wkład w rozwiązywanie wspomnianych problemów i stanowi ważny element zrównoważonego rozwoju na świecie. Twórcy założeń zreformowanej europejskiej polityki rolnej z pewnością zdawali sobie z tego dobrze sprawę. Skupienie szczególnej uwagi na rozwoju lokalnych systemów żywności pozwala bowiem osiągnąć główne cele polityki rolnej, zwłaszcza zachowanie bezpieczeństwa żywnościowego i żywności, m.in. dzięki utrzymaniu lokalnych zdolności wytwórczych, zapewnieniu transparentnego procesu produkcji żywności oraz dbaniu o zrównoważony rozwój całego sektora rolno-spożywczego Unii Europejskiej.

Warto nadmienić, że trwałe i rosnące zainteresowanie lokalnymi systemami żywności jest także wynikiem rozwijania się na skalę światową zjawiska tzw. prosumpcji, które dotyczy również sektora żywnościowego. Jedną z przesłanek jego rozwoju jest odejście od standaryzacji gustów i chęć aktywnego włączenia się konsumentów w kierunki produkcji żywności lokalnej, ekologicznej i opartej na krótkich łańcuchach dostaw. Zainteresowanie lokalnymi czy regionalnymi towarami wykazują nie tylko producenci i konsumenci, ale również przedstawiciele ogniw pośredniczących w dostawach produktów, tj. restauracje i supermarkety, także dopasowujące swoją ofertę do bieżących oczekiwań nabywców.

\section{Bibliografia}

Agenda 21 (2017), https://sustainabledevelopment.un.org/content/documents/ Agenda21.pdf.

Borowiec J. (2011), Ekonomia integracji europejskiej, Wyd. UE, Wrocław.

Cel 12: Zapewnić wzorce zrównoważonej konsumpcji i produkcji (2017), http:// www.un.org.pl/cel12.

Definicja krótkich łańcuchów żywności (KŁŻ) (2017), http://produktlokalny.pl/ wp-content/uploads/2016/10/PL-Definicja-K\%C5\%81\%C5\%BB-1.pdf. 
Europa 2020 - cele (2017), http://ec.europa.eu/europe2020/europe-2020-in-a-nutshell/targets/index_pl.htm.

Hardaker J.B. (2017), Guidelines for the integration of sustainable agriculture and rural development into agricultural policies, www.fao.org/docrep/w7541-e/ w7541e00.HTM.

Health Check of the Common Agricultural Policy (2017), http://ec.europa.eu/agriculture/healthcheck_pl.

Food Miles Calculator (2017), www.foodmiles.com.

Kociszewski K. (2013), Ekologizacja polskiego rolnictwa a zrównoważony rozwój w warunkach członkostwa w Unii Europejskiej, Wyd. UE, Wrocław.

Komunikat Komisji do Parlamentu Europejskiego, Rady, Europejskiego Komitetu Ekonomiczno-Społecznego i Komitetu Regionów. WPR do 2020 roku: sprostać wyzwaniom przyszłości związanym z żywnością, zasobami naturalnymi oraz aspektami terytorialnymi (2010), KOM 672, 18.11.2010, www.europarl.europa.eu/meetdocs/2009_2014/documents/com/com_com(2010)0672_/com_ com(2010)0672_pl.pdf.

Komunikat prasowy. Porozumienie polityczne w sprawie nowego kierunku wspólnej polityki rolnej (2013), http://europa.eu/rapid/press-release_IP-13613 pl.htm.

Local Food and Short Supply Chains (2012), „EU Rural Review”, nr 12, http:// enrd.ec.europa.eu/enrd-static/fms/pdf/E8F24E08-0A45-F272-33FBA6309E3AD601.pdf.

Michalczyk J. (2014), Ewolucja polityki rolnej Unii Europejskiej na tle koncepcji zrównoważonego rozwoju [w:] Rymarczyk J., Domiter M., Michalczyk W. (red.), „Prace Naukowe Uniwersytetu Ekonomicznego we Wrocławiu” $\mathrm{nr}$ 369. Przemiany strukturalne i koniunkturalne na światowych rynkach, t. 1, Wyd. UE, Wrocław.

Milenijne cele rozwoju (2017), www.unic.un.org.pl/cele.php.

Morżoł I. (2017), UNESCO a zrównoważony rozwój, www.unesco.pl/edukacja/ dekada-edukacji-nt-zrownowazonego-rozwoju/unesco-a-zrownowazonyrozwoj.

Notatka. Reforma wspólnej polityki rolnej (WPR) - wyjaśnienie najważniejszych ele-mentów (2013), http://europa.eu/rapid/press-release_MEMO-13-621_ pl.htm.

Pawłowski A., Pawłowski L. (2014), Warunki trwałego i zrównoważonego rozwoju ludzkości [w:] Galwas B., Wyżnikiewicz B. (red.), Czy kryzys światowych zasobów?, PAN, Warszawa.

Projekt opinii perspektywicznej Komitetu Regionów „Lokalne systemy żywnościowe” (2017), https://webapi.cor.europa.eu/documentsanonymous/CDR341-2010_ REV1_PAC_PL.doc.

Raszeja-Ossowska I. (2017), Cykle dostaw i systemy jakości w rolnictwie, www. dotacje.pl/dla-rolnikow/cykle-dostaw-i-systemy-jakosci-w-rolnictwie. 
Rezolucja Parlamentu Europejskiego z dnia 23 czerwca 2011r. w sprawie WPR do 2020 r.: sprostać wyzwaniom przyszłości związanym z żywnością, zasobami naturalnymi oraz aspektami terytorialnym (2011), P7_TA 0297, www. europarl.europa.eu/sides/getDoc.do?pubRef=-//EP//NONSGML+TA+P7TA-2011-0297+0+DOC+PDF+V0//PL.

Sprawozdanie Komisji dla Parlamentu Europejskiego i Rady w sprawie systemu etykietowania dotyczącego rolnictwa lokalnego i sprzedaży bezpośredniej (2013), COM 866, 06.12.2013, http://eur-lex.europa.eu/resource.html?uri=cellar:be106719-60e5-11e3-ab0f-01aa75ed71a1.0006.01/ DOC_1\&format $=$ PDF.

Szczyt Ziemi 1992 (2017), http://pl.wikipedia.org/wiki/Szczyt_Ziemi_1992.

Szczyt Ziemi 2002 (2017), http://pl.wikipedia.org/wiki/Szczyt_Ziemi_2002.

Świderska A. (2017), Programy rolnośrodowiskowe szansą na petniejsza ochrone różnorodności biologicznej i krajobrazowej obszaru polskiej wsi, http:// archiwum.ekoportal.gov.pl/warto_wiedziec_i_odwiedzic/artykuly/OchronaRoznorodnosciBiologicznejWsi.html.

Wilkin J. (2017), Rolnictwo - funkcje teraz i w przyszłości, http://ppg.ibngr.pl/ pomorski-przeglad-gospodarczy/rolnictwo-funkcje-teraz-i-w-przyszlosci.

Wstępny zarys. Program Rozwoju Obszarów Wiejskich 2014-2020 (2013), www.arimr.gov.pl/fileadmin/pliki/dokumenty/Zarys_PROW_2014-2020_ 15042013.pdf.

Wystąpienie Sekretarza Generalnego ONZ dotyczące rezultatów Konferencji Rio+20 (2017), www.unic.un.org.pl/aktualnosci.php?news $=2305 \&$ wid $=18$.

Wyżnikiewicz B. (2014), Realność trwatego i zrównoważonego rozwoju - perspektywa 2050 roku [w:] Galwas B., Wyżnikiewicz B. (red.), Czy kryzys światowych zasobów?, PAN, Warszawa.

Zegar J.S. (2012), Współczesne wyzwania rolnictwa, PWN, Warszawa.

Żmija D. (2014), Zrównoważony rozwój rolnictwa i obszarów wiejskich w Polsce, „Studia Ekonomiczne - Zeszyty Naukowe”, nr 166, s. 149-158.

Żywność lokalna i krótkie łańcuchy dostaw (2017), http://enrd.ec.europa.eu/enrdstatic/themes/local-food-and-short-supply-chains/p1/local-food-and-shortsupply-chains_pl.html.

\section{Streszczenie}

Celem niniejszego opracowania jest określenie znaczenia lokalnej żywności oraz krótkich łańcuchów dostaw we wdrażaniu koncepcji zrównoważonego rozwoju rolnictwa i obszarów wiejskich oraz przedstawienie działań Unii Europejskiej w tym zakresie. Działania te są prowadzone na podstawie Wspólnej Polityki Rolnej. 
W celu przygotowania tekstu posłużono się metodą opisową oraz analizą literatury. W kontekście różnorodnych wyzwań współczesnej gospodarki światowej, rozwój lokalnych systemów żywności, oznaczających produkcję, przetwórstwo i obrót na stosunkowo małym obszarze, jest szczególnie ważny. Ma on istotny wkład $\mathrm{w}$ rozwiązywanie problemów wynikających $\mathrm{z}$ postępującej globalizacji i stanowi ważny element zrównoważonego rozwoju na świecie. Przywiązywanie szczególnej wagi w polityce rolnej Unii Europejskiej do rozwoju lokalnych systemów żywności pozwala osiągać jej główne cele, zwłaszcza zachowanie bezpieczeństwa żywnościowego i żywności, m.in. dzięki utrzymaniu lokalnych zdolności wytwórczych, zapewnieniu transparentnego procesu produkcji żywności oraz dbaniu o zrównoważony rozwój całego sektora rolno-spożywczego.

Słowa kluczowe: żywność lokalna, krótkie łańcuchy dostaw, zrównoważony rozwój rolnictwa i obszarów wiejskich, Unia Europejska

\section{Summary}

The importance of local food and short supply chains in shaping sustainable development of agriculture and rural areas in the European Union

The aim of the article is to indicate the importance of local food and short supply chains in the implementation of the concept of the sustainable development of agriculture and rural areas, and to present the European Union's actions in this field. These actions are concentrated in the Common Agricultural Policy. When preparing the text, the descriptive method and an analysis of the literature were utilised. In the context of diverse challenges facing the economy of the modern world, the development of local food systems, meaning production, processing and trade in a relatively small area, is particularly important. It brings an important contribution to solving the problems arising from progressive globalisation and constitutes a significant element of sustainable development around the world. Focusing attention on the development of local food systems in the agricultural policy of the European Union allows its main objectives to be realized, in particular the preservation of food security and safety, through maintaining local production capacity, ensuring a transparent process of food production and caring for sustainable development of the entire agri-food sector, among others.

Keywords: local food, short supply chains, sustainable development of agriculture and rural areas, European Union

JEL: Q01, Q18 